\title{
PENERAPAN MODEL PEMBELAJARAN KOOPERATIF TIPE THINK PAIR SHARE (TPS) TERHADAP KEMAMPUAN BERPIKIR KREATIF PESERTA DIDIK DI SMA NEGERI 12 MAKASSAR
}

\author{
*Syahrul Mubarak \\ Universitas Negeri Makassar \\ syahrul.mubarak.bk71@gmail.com \\ Aisyah Azis \\ Universitas Negeri Makassar \\ aisyahazisunm@gmail.com \\ Abdul Haris \\ Universitas Negeri Makassar \\ abd.haris@unm.ac.id
}

*koresponden author
Abstrak - Penelitian ini bertujuan untuk mengetahui tingkat kemampuan berpikir kreatif peserta didik yang diajar dengan menggunakan model pembelajaran Kooperatif tipe Think Pair Share (TPS) pada mata pelajaran fisika peserta didik kelas XI MIA SMA Negeri 12 Makassar. Penelitian ini merupakan penelitian pre eksperimen dengan desain One-Shot Case Study. Penelitian ini dilaksanakan di SMA Negeri 12 Makassar tahun ajaran 2019/2020 dengan jumlah sampel kelas XI MIA 2 yang berjumlah 28 peserta didik. Alat pengumpul data menggunakan instrumen tes berupa tes kemampuan berpikir kreatif peserta didik. Hasil penelitian berdasarkan analisis statistik deskriktif menunjukkan bahwa kemampuan berpikir kreatif peserta didik pada indikator fluenty sebesar $88,57 \%$, flexibility sebesar $67,86 \%$, originality sebesar $63,57 \%$, dan elaboration sebesar 82,14\%. Secara keseluruhan, skor rata-rata tes kemampuan berpikir kreatif peserta didik kelas XI SMA Negeri 12 Makassar yang diajar menggunakan model pembelajaran Kooperatif tipe Think Pair Share (TPS) berada di atas $70 \%$ yakni $75,54 \%$ dari skor ideal. Adapun berdasarkan kemampuan berpikir kreatif peserta didik ditinjau dari jenis kelaminnya, kelompok laki-laki lebih dominan dibandingkan perempuan pada materi elastisitas.

Kata Kunci : Berpikir Kreatif, Kooperatif, Think Pair Share (TPS)

Abstract - This research aims to determine the level of creative thinking ability of students taught using the Cooperative learning model Think Pair Share (TPS) type in physics learning in class XI MIA at Senior High School 12 Makassar. This research was implemented in academic year 2019/2020 with 28 students as research subjects. The data collection tool uses a test instrument in the form of a test of students creative thinking abilities. The results of the study based onstatistic descriptive analysis showed that students' creative thinking ability on fluenty indicators was $88.57 \%$, flexibility was $67.86 \%$, originality was $63.57 \%$, and elaboration was $82.14 \%$. Overall, the average score of students creative thinking ability test results taught using the Cooperative Learning Model Think Pair Share (TPS) more than $70 \%$ type was $75.54 \%$ of the ideal score. According creative thinking ability of students in terms of gender, the male group is more dominant than the female group in elasticity material.

Keywords : Creative Thinking, Cooperative, Think Pair Share (TPS) 


\section{A. PENDAHULUAN}

Pendidikan sebagai media strategis pengembangan sumber daya manusia masih menjadi sorotan sampai saat ini, kualitas dan kuantitas pendidikan masih tetap merupakan masalah yang paling menonjol dalam setiap pembaharuan sistem pendidikan nasional. Kedua masalah tersebut sulit ditangani secara simultan, sebab dalam upaya peningkatan kualitas dan kuantitas kadang terabaikan, demikian pula sebaliknya. Dengan demikian pemerintah khususnya Kementrian Pendidikan Nasional telah berusaha melakukan berbagai upaya mengatasi masalah pendidikan, seperti perbaikan kurikulum, peningkatan kualitas guru, pengadaan sarana dan prasarana belajar, penyempurnaan sistem penilaian, serta usaha-usaha lain yang berkaitan dengan kualitas pendidikan.

Salah satu cara yang dapat ditempuh dalam pembelajaran fisika agar mutu pembelajaran dapat ditingkatkan adalah dengan mengintensifkan pengembangan kemampuan peserta didik dalam memecahkan masalah fisika sebagai pemeriksaan hasil belajar melalui proses-proses sains dengan menggunakan metode ilmiah atau metode keilmuan yang merupakan prosedur untuk mendapatkan ilmu.

Namun dewasa ini pembelajaran fisika yang dikembangkan di sekolah-sekolah memeiliki kecenderungan antara lain (1) kebanyakan hitung-hitungan dan kurang berhubungan dengan kehidupan nyata peserta didik, (2) peserta didik belajar dengan ketakutan karena sulitnya pelajaran, (3) kurang mendorong peserta didik untuk berpikir kreatif dan kritis, (4) jarang melatihkan pemecahan masalah serta kurang menanamkan nilai-nilai kearifan lokal dalam pembelajaran sains. Jika peserta didik masih terpaku pada tingkat pengetahuan yang bersifat hafalan saja, maka akan sulit menghadapi persaingan global yang tidak hanya menuntut seorang individu menjadi pintar dan cerdas saja melainkan dituntut juga kreativitasnya.

Kreativitas peserta didik kurang diperhatikan dan diapresiasi dalam proses pembelajaran ini menyebabkan peserta didik tidak mau bahkan takut untuk melakukan sesuatu hal yang baru. Padahal kreatif bukan hanya kemampuan untuk menghasilkan produk saja melainkan kemampuan menciptakan sebuah solusi yang tidak terpaku pada satu jawaban benar pun dapat dikatakan kreatif.

Kemampuan belajar kreatif erat kaitannya dengan hasil belajar peserta didik. Semakin tinggi kreativitas peserta didik, maka semakin besar pula peluangnya untuk mencapai tujuan dari pendidikan. Hasil belajar yang diperoleh peserta didik sangat berkaitan erat dengan kreativitas yang dimilikinya. Dalam penelitiannya, Boty \& Handoyo (2018) mengatakan bahwa kreativitas berfungsi penuh terhadap peningkatan hasil belajar. Dalam penelitian lain, dikatakan bahwa kemampuan berpikir kreatif peserta didik memiliki korelasi yang positif terhadap hasil belajar peserta didik. Menurut Munandar dalam penelitian yang dilakukan oleh Supardi (2012), "dari hasil studi korelasi dan analisis faktor membuktikan tes kreativitas sebagai dimensi fungsi kognitif yang relatif bersatu yang dapat dibedakan dari tes intelegensi; tetapi berpikir divergen (kreativitas) juga menunjukkan hubungan yang bermakna dengan berpikir konvergen (intelengsi)". Hal ini membuktikan bahwa terdapat hubungan yang erat 
antara kreativitas atau berpikir kreatif dengan intelegensi seseorang, atau dalam hal ini dapat dikaitkan dengan hasil belajar.

Kreativitas juga memiliki andil yang besar terhadap hasil belajar peserta didik. Dalam penelitiannya, Nuriadin \& Perbowo (2013) mengatakan bahwa kemampuan berpikir kreatif memiliki kontribusi sebesar 31,2\% terhadap peningkatan hasil belajar peserta didik. Artinya, sepertiga dari dari faktor yang mempengaruhi hasil belajar adalah kemampuan berpikir kreatif. Jika terdapat masalah pada hasil belajar peserta didik, maka kemampuan berpikir kreatifnya juga sedang bermasalah.

Sudah banyak penelitian yang dilakukan untuk meningkatkan kualitas pendidikan, terkhusus kemampuan berpikir kreatif peserta didik, salah satunya adalah penelitian yang dilakukan oleh Ika Humaeroh dari Universitas Islam Negeri Syarif Hidayatullah Jakarta. Namun, hasil yang diperoleh bisa dikatakan belum terlalu optimal. Untuk itu perlu dilakukan penelitian untuk melihat pengaruh terhadap kemampuan berpikir kreatif peserta didik dengan menggunakan model pembelajaran yang lain.

Salah satu model pempelajaran yang dapat dikembangkan di kelas dan mampu memfasilitasi pengembangan keterampilan berpikir kreatif dan memungkinkan peserta didik untuk berinteraksi satu sama lain adalah model pembelajaran Kooperatif tipe Think Pair Share (TPS). Model pembelajaran Kooperatif tipe Think Pair Share (TPS) dapat membantu peserta didik dalam mengembangkan keterampilan dasar serta pemecahan masalah yang kompleks, serta memberi kesempatan kepada setiap peserta didik untuk menunjukkan partisispasinya kepada orang lain. Penerapan model pembelajaran Kooperatif tipe Think Pair Share (TPS) dapat mengembangkan keterampilan berpikir dan menjawab dalam komunikasi antara satu dengan yang lain, serta bekerja saling membantu dalam kelompok kecil. Dalam hal ini, guru sangat berperan penting untuk membimbing peserta didik melakukan diskusi, sehingga terciptanya suasana belajar yang lebih hidup, aktif, kratif, efektif dan menyenangkan.

Banyak penelitian yang menyatakan bahwa model pembelajaran Kooperatif tipe Think Pair Share (TPS) memberikan pengaruh yang positif terhadap pembelajaran. Hasil penelitian yang dilakukan oleh Desia, menyampaikan bahwa peserta didik yang belajar mengikuti model pembelajaran Kooperatif tipe Think Pair Share (TPS) secara signifikan memiliki kemampuan berpikir kreatif yang lebih baik dari peserta didik yang mengikuti model pembelajaran konvensional. Model pembelajaran Kooperatif tipe Think Pair Share (TPS) diterapkan dalam usaha untuk melatih kemampuan berpikir kreatif peserta didik.

Adapun tujuan yang ingin dicapai dalam penelitian ini adalah mengetahui tingkat kemampuan berpikir kreatif peserta didik yang diajar dengan menggunakan model pembelajaran Kooperatif tipe Think Pair Share (TPS) pada mata pelajaran fisika peserta didik kelas XI MIA SMA Negeri 12 Makassar. 


\section{B. METODE}

Penelitian ini dilaksanakan pada semester ganjl tahun ajaran 2019/2020 di SMA Negeri 12 Makassar tepatnya pada bulan Agustus 2019. Dalam penelitian ini yang menjadi populasi adalah peserta didik kelas XI MIA SMA Negeri 12 Makassar dan sampel yaitu peserta didik kelas XI MIA 2 yang terdiri dari 28 peserta didik. Penelitian ini melibatkan dua variabel, yaitu variabel bebas dan terikat. Variabel bebas dalam penelitian ini adalah model pembelajaran Kooperatif tipe Think Pair Share (TPS) dan variabel terikat adalah kemampuan berpikir kreatif.

Penelitian ini merupakan penelitian Pre-Experimental Design dengan desain One-Shot Case Study dengan paradigma sebagai berikut

\section{X $\mathbf{O}$}

Keterangan:

$\mathrm{X}=$ Treatment yang diberikan (model pembelajaran Kooperatif tipe Think Pair Share (TPS))

$\mathrm{O}=$ Tes kemampuan berpikir kreatif

Langkah-langkah yang dilaksanakan pada penelitian ini terbagi atas tiga tahap yaitu tahap persiapan, tahap pelaksanaan, dan tahap akhir.

Metode pengumpulan data yang digunakan adalah metode tes kemampuan berpikir kreatif peserta didik dengan empat butir soal, setiap butir mewakili satu indikator kemampuan berpikir kreatif. Setiap indikator diberikan skor pada interval 0-5. Pemberian masing-masing skor disesuaikan dengan pedoman penskoran yang telah dibuat. Instrumen yang digunakan telah melewati tahap validasi oleh validator.

Untuk menganalis data yang diperoleh, digunakan teknik analisis deskriktif dan analisis uji hipotesis. Analisis deskriktif dimaksudkan untuk mendeskripsikan distribusi skor tes kemampuan berpikir kreatif fisika peserta didik kelas XI MIA SMA Negeri 12 Makassar yang kemudian ditampilkan dalam bentuk tabel, grafik, skor rata-rata, standar deviasi, dan perhitungan presentase. Hasil tes kemampuan berpikir kreatif peserta didik kemudian dikelompokkan dan dikategorikan dengan kategori sebagai berikut:

Tabel 1. Kategori Skor Tes Kemampuan Berpikir Kreatif

\begin{tabular}{cc}
\hline Interval Skor & Kategori \\
\hline $14-20$ & Tinggi \\
$7-13$ & Sedang \\
$0-6$ & Rendah \\
\hline
\end{tabular}

(Utami \& Kuneni, 2016) 


\section{HASIL DAN PEMBAHASAN}

Hasil yang diperoleh pada penelitian ini berupa data skor tes kemampuan berpikir kreatif peserta didik. Variabel kemampuan berpikir kreatif peserta didik diukur dengan menggunakan tes uraian berjumlah 4 butir, dengan skor ideal minimal yaitu 0 dan skor ideal maksimal yaitu 20. Hasil perhitungan skor kemampuan berpikir kreatif peserta didik yang berjumlah 28 orang memperoleh skom maksimal 19 dan skor minimal 6, dengan rata-rata 15,11, modus 16, dan standar deviasi 3,42. Berdasarkan skala penilaian, skor rata-rata tes kemampuan berpikir kreatif peserta didik berada pada kategori tinggi. Adapun penyebaran kategori hasil tes kemampuan berpikir kreatif peserta didik adalah sebagai berikut:

\begin{tabular}{|c|c|c|c|}
\hline $\begin{array}{c}\text { Interval } \\
\text { Skor }\end{array}$ & Kategori & Frekuensi & $\begin{array}{c}\text { Persentase } \\
(\%)\end{array}$ \\
\hline $14-20$ & Tinggi & 22 & 78,57 \\
\hline $7-13$ & Sedang & 4 & 14,28 \\
\hline $0-6$ & Rendah & 2 & 7,14 \\
\hline \multicolumn{2}{|c|}{ Jumlah } & 28 & 100 \\
\hline
\end{tabular}

Dalam penelitian ini, indikator kemampuan berpikir kreatif yang diujikan ada empat indikator, yaitu indikator fluenty, flexibility, originality, dan elaboration. Dari empat indikator kemampuan berpikir kreatif yang diujikan, indikator fluenty merupakan indikator dengan persentase perolehan paling tinggi yaitu 88,57\%. Hal ini menunjukkan bahwa sebagian besar peserta didik sudah mampu untuk berpikir lancar, dimana peserta didik dapat mengaitkan konsep fisika dengan pemanfaatannya dalam kehidupan sehari-hari, meskipun masih terbilang sederhana. Adapun indikator dengan persentase perolehan terendah yaitu indikator oiginality dengan persentase ketercapaian sebesar $63,57 \%$. Hal ini dikarenakan ciri utama dari kreativitas itu ada pada indikator originality ini, yang mana hal baru merupakan produk utama dari kreativitas, dalam hal ini produk baru tersebut dalam bentuk persamaan yang diperoleh dari menggabungkan beberapa persamaan umum, dan persamaan tersebut tidak tersurat dalam buku ataupun media belajar yang lainnya. Adapun persentase perolehan untuk indikator flexibility dan elaboration masing-masing yaitu $67,86 \%$ dan $82,14 \%$.

Hasil tes kemampuan berpikir kreatif peserta didik yang diperoleh dipengaruhi oleh variabel bebas sekaligus perlakuan yang diberikan kepada peserta didik, yaitu kegiatan pembelajaran dengan menggunakan model pembelajaran Kooperatif tipe Think Pair Share (TPS). Model pembelajaran ini memungkinkan seluruh peserta didik mengambil bagian di dalamnya. Hal ini dikarenakan dalam melakukan diskusi dibutuhkan minimal dua orang yang 
saling berinteraksi, dan dalam model pembelajaran ini kelompok dibagi berdasarkan teman duduk, sehingga setiap kelompok hanya beranggotakan dua orang, kecuali pada saat jumlah peserta didik sedang dalam keadaan berjumlah ganjil atau ada peserta didik yang tidak memiliki teman sebangku, maka guru mensiasati dengan mempersilahkan 1 kelompok beranggotakan 3 orang. Bukan hanya dalam kelompok dilakukan diskusi, tetapi setelah berdiskusi pada setiap kelompok, akan ditunjuk satu orang dari setiap kelompok untuk naik mempresentasikan hasil diskusinya dengan teman sebangkunya.

Penerapan model pembelajaran kooperatif tipe Think Pair Share dapat meningkatkan keterampilan proses sains siswa secara keseluruhan dan dapat meningkatkan keterampilan berpikir tingkat tinggi siswa, salah satunya berpikir kreatif. Hal ini dikarenakan TPS dapat melibatkan siswa secara aktif dalam proses pembelajaran, mengungkapkan ide dan menerima umpan balik yang cepat. Dengan keterlibatan penuh setiap peserta didik dalam kegiatan pemebelajaran akan merangsang keterampilan berpikir kreatif peserta didik. Selain itu, TPS dapat melibatkan peserta didik secara aktif dalam proses pembelajaran, mengungkapkan ide dan menerima umpan balik yang cepat sehingga dapat merangsang keterampilan berpikir peserta didik (Kothiyal et al., 2013)

Pembelajaran kooperatif tipe Think Pair Share dapat meningkatkan proses kognitif peserta didik. Tahap think (berpikir) dapat membantu peserta didik menggunakan pendekatan untuk menyelesaikan masalah sehingga siswa lebih siap menghadapi masalah dengan solusi yang inovatif. Tahap ini diharapkan mampu untuk meningkatkan kemampuan berpikir kreatif peserta didik dimana peserta didik telah mampu untuk menghasilkan solusi dari sebuah masalah atau fenomena yang diajukan oleh guru (Razzouk \& Shute, 2012).

Tahap pair (berpasangan) dan share (berbagi), peserta didik akan saling membantu dengan berbagi ide, pendapat, dan pikiran untuk menjawab pertanyaan-pertanyaan yang diberikan oleh guru kepada mereka. Tahapan ini akan mereka lakukan dengan bermodalkan solusi inovatif yang mereka peroleh pada tahap sebelumnya, sehingga akan ada berbagai ideide yang akan saling dipertemukan dan didiskusikan. Dengan berbagi ide, peserta didik akan memperoleh pengetahuan baru (Sugiarto \& Sumarsono, 2014).

Dalam model pembelajaran ini, tahapan pair dan share menjadi ciri bahwa model pembelajaran ini tergolong dalam model pembelajaran kooperatif. Proses diskusi yang dilakukan ini dapat meningkatkan proses berpikir kraeatif dan merefleksi diri untuk lebih memahami materi secara menyeluruh (Kwok \& Lau, 2015).

Dari empat indikator kemampuan berpikir kreatif yang diujikan, indikator fluenty merupakan indikator dengan persentase perolehan paling tinggi yaitu 88,57\%. Hal ini 
menunjukkan bahwa sebagian besar peserta didik sudah mampu untuk berpikir lancar, dimana peserta didik dapat mengaitkan konsep fisika dengan pemanfaatannya dalam kehidupan seharihari, meskipun masih terbilang sederhana. Adapun indikator dengan persentase perolehan terendah yaitu indikator oiginality dengan persentase ketercapaian sebesar 63,57\%. Hal ini dikarenakan ciri utama dari kreativitas itu ada pada indikator originality ini, yang mana hal baru merupakan produk utama dari kreativitas, dalam hal ini produk baru tersebut dalam bentuk persamaan yang diperoleh dari menggabungkan beberapa persamaan umum, dan persamaan tersebut tidak tersurat dalam buku ataupun media belajar yang lainnya. Adapun persentase perolehan untuk indikator flexibility dan elaboration masing-masing yaitu $67,86 \%$ dan $82,14 \%$.

Adapun pengelompokan berdasarkan jenis kelamin, hasil penelitian menunjukkan bahwa kemampuan berpikir kreatif peserta didik antara kelompok laki-laki dengan kelompok perempuan terdapat perbedaan. Secara deskriktif, skor rata-rata tes kemampuan berpikir kreatif peserta didik kelompok laki-laki lebih tinggi dibandingkan dengan kelompok perempuan dimana skor rata-rata yaitu 15,21 untuk kelompok laki-laki berbanding 15,00 untuk kelompok perempuan.

Perbedaan jenis kelamin membuat setiap individu berbeda dengan individu lainnya, seperti laki-laki berbeda dibandingkan dengan perempuan dalam banyak aspek termasuk dalam hal kecerdasan, minat, ingatan, emosi dan kemauan. Secara umum laki-laki bersifat lebih aktif, memberi, melindungi, meniru pribadi yang menurutnya menarik dan lebih berminat pada hal-hal yang berkaitan dengan intelektual. Sedangkan perempuan cenderung bersifat pasif dan menerima, ingin dilindungi, dan lebih berminat pada hal-hal yang bersifat emosional. Perbedaan potensi dan kecenderungan sifat yang dimiliki antara laki-laki dan perempuan terjadi karena perbedaan perkembangan fisik dan psikis yang terjadi antara keduanya. Perbedaan ini tentu berpengaruh pada kemampuan laki-laki dan perempuan dalam berpikir (Pramawati, Dantes, \& Parmiti, 2016).

\section{SIMPULAN}

Berdasarkan hasil dan pembahasan di atas maka dapat disimpulkan bahwa skor rata-rata tes kemampuan berpikir kreatif peserta didik kelas XI SMA Negeri 12 Makassar yang diajar menggunakan model pembelajaran Kooperatif tipe Think Pair Share (TPS) berada di atas 70\% yakni 75,54\% dari skor ideal. Adapun berdasarkan kemampuan berpikir kreatif peserta didik ditinjau dari jenis kelaminnya, kelompok laki-laki lebih dominan dibandingkan perempuan pada materi elastisitas. 


\section{DAFTAR RUJUKAN}

Boty, M., \& Handoyo, A. 2018. Hubungan Kreativitas Dengan Hasil Belajar Siswa Kelas V Mata Pelajaran Bahasa Indonesia Di Mi Ma’had Islamy Palembang. JIP: Jurnal Ilmiah PGMI. 4, $41-55$.

Kothiyal, A., Majumdar, R., Murthy, S., \& Iyer, S. 2013. Effect of think-pair-share in a large CS1 class: $83 \%$ sustained engagement. 137-144. ACM.

Kwok, A. P., \& Lau, A. 2015. An exploratory study on using the think-pair-share cooperative learning strategy. Journal of Mathematical Sciences. 2, 22-28.

Nuriadin, I., \& Perbowo, Krisna Satrio. 2013. Amalisis Korelasi Kemampuan Berpikir Kreatif Matematik Terhadap Hasil Belajar Matematika Peserta Didik SMP Negeri 3 Lurangung Kuningan Jawa Barat. Jurnal Ilmiah Program Studi Matematika STKIP Siliwangi Bandung. Vol. 2, No. 1.

Pramawati, N. M. N., Dantes, N., \& Parmiti, D. P. 2016. Pengaruh Model Pembelajaran Kooperatif tipe Think Pair Share (TPS) terhadap Keterampilan Berpikir Kreatif Ditinjau dari Jenis Kelamisn pada Siswa Kelas V. 4.

Razzouk, R., \& Shute, V. (2012). What is design thinking and why is it important? Review of Educational Research. 82 (3), 330-348.

Sugiarto, D., \& Sumarsono, P. 2014. The Implementation of Think-Pair-Share Model to Improve Students' Ability in Reading Narrative Texts. International Journal of English and Education. 3 (3), 206-215.

Sugiyono. 2017. Metode Penelitian Pendidikan. Bandung: Alfabeta.

Supardi. 2012. Peran berpikir kreatif dalam proses pembelajaran matematika. Jurnal Formatif. 2 (3), $248-262$.

Utami, A. K. D., \& Kuneni, E. 2016. Analisis Tingkat Kemampuan Berpikir Kreatif Pada Materi Geometri Ditinjau Dari Kemampuan Awal (Pada Siswa Kelas VII SMP Negeri 2 Kedu Kabupaten Temanggung Tahun Pelajaran 2014/2015). Presented at the Prosiding Seminar Nasional Matematika dan Pendidikan Matematika. 